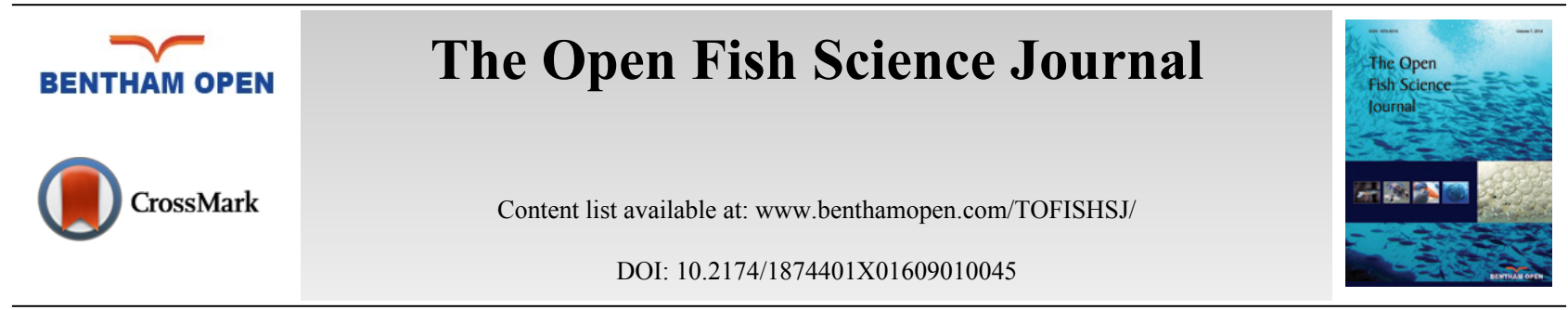

RESEARCH ARTICLE

\title{
Summer-Autumn Habitat Use of Yearling Rainbow Trout in Two Streams in the Lake Ontario Watershed
}

\author{
James H. Johnson", James E. McKenna and Marc A. Chalupnicki \\ Tunison Laboratory of Aquatic Science, USGS - Great Lakes Science Center, 3075 Gracie Road, Cortland, NY 13045, \\ USA
}

\begin{abstract}
Understanding the habitat requirements of salmonids in streams is an important component of fisheries management. We examined the summer and autumn habitat use of yearling Rainbow Trout Oncorhynchus mykiss in relation to available habitat in two streams in the Lake Ontario watershed. Little interstream variation in trout habitat use was observed; the variation that did occur was largely due to differences between streams in available habitat in the autumn. In both streams, yearling Rainbow Trout utilized pool habitat and during periods of high stream discharge were associated with larger substrate that may provide a velocity barrier. These findings may assist resource managers in their efforts to protect and restore habitat for migratory Rainbow Trout in the Lake Ontario watershed.
\end{abstract}

Keywords: Autumn, Habitat, Rainbow trout, Streams, Summer.

\section{INTRODUCTION}

Juvenile salmonid populations in streams are governed by both intraspecific and interspecific associations [1]. Intraspecific interactions in pool habitats are often associated with hierarchies, whereas territories are established in riffle and glide habitats [2]. As juvenile salmonids grow, territories increase in size, resulting in a concomitant decrease in fish density [3]. Consequently, in the case of migratory salmonids where juveniles occupy streams before outmigrating to lotic ecosystems, it is important to understand habitat requirements of the largest life stage because their territories encompass most of the usable salmonid habitat.

Rainbow Trout Oncorhynchus mykiss are native to western North America and were introduced into the Great Lakes around 1870 [4]. Rainbow Trout are now naturalized in the Great Lakes with populations established in every lake [4]. In many streams in the Lake Ontario basin, juvenile Rainbow Trout make up the most biomass of any salmonid species [5]. In tributaries to Lake Ontario, Rainbow Trout have filled the niche of formerly native, but extirpated Atlantic Salmon Salmo salar [5, 6]. Similar to Atlantic Salmon, juvenile Rainbow Trout spend two years in tributaries before descending to Lake Ontario [7]. The two year stream residence time of Rainbow Trout in Great Lakes tributaries makes understanding variation in the selection and use of habitat variables especially important in the context of efforts to restore Atlantic Salmon in the Lake Ontario watershed.

Habitat selection of yearling Rainbow Trout in streams has been observed to vary within [8] and among [9] streams as well as between seasons [10]. Variation in yearling steelhead (Rainbow Trout) habitat use in different sections of the Bridge River, British Columbia were attributed to differences in available habitat between the river reaches [8]. Variation in the habitat use of yearling steelhead has also been observed in streams from the Coast and Cascade Ranges in Oregon [9]. Seasonal variation in the habitat use of yearling Rainbow Trout has also been documented in tributaries of the White River in Vermont [10]. Recognizing which life history specific habitat requirements create bottlenecks for

\footnotetext{
* Address correspondence to this author at the Tunison Laboratory of Aquatic Science, USGS - Great Lakes Science Center, 3075 Gracie Road, Cortland, NY 13045, USA; Tel: (607) 753-9391 x7530; Fax: (607)753-0258; E-mail: jhjohnson@usgs.gov
} 
populations is critical for effective fish species management [11]. The objectives of this study were to examine within and among stream variability in the habitat selection of yearling Rainbow Trout in summer and fall.

\section{MATERIALS \& METHODOLOGY}

Yearling Rainbow Trout habitat use was examined during summer (mid-July) and autumn (mid-October) on several occasions in 2010 and 2011 in two third-order streams in the Lake Ontario watershed in central New York (Fig. 1). Grout Brook drains an area of approximately 2,455 ha before discharging into Skaneateles Lake. Orwell Brook drains an area of 12,914 ha before discharging into the Salmon River, approximately $21 \mathrm{~km}$ from the river's confluence with Lake Ontario. August and October discharge in Grout Brook is about $0.00048 \mathrm{~m}^{3} \cdot \mathrm{s}^{-1} \cdot \mathrm{km}^{-2}$ and $0.00112 \mathrm{~m}^{3} \cdot \mathrm{s}^{-1} \cdot \mathrm{km}^{-2}$ and in Orwell Brook about $0.00091 \mathrm{~m}^{3} \cdot \mathrm{s}^{-1} \cdot \mathrm{km}^{-2}$ and $0.00218 \mathrm{~m}^{3} \cdot \mathrm{s}^{-1} \cdot \mathrm{km}^{-2}$. The streams have similar physical characteristics including a $3 \%$ gradient, gravel/cobble substrate, a mean wetted width of 4.0-4.4 m, good riparian overstory, and summer stream temperatures that seldom exceed $19^{\circ} \mathrm{C}$. Rainbow Trout in both streams are migratory with adults from Lake Ontario (Orwell Brook) and Skaneateles Lake (Grout Brook) ascending each stream to spawn. Juvenile Rainbow Trout $(0+$ and $1+)$ comprise the dominant fish biomass in each stream with Slimy Sculpin Cottus cognatus being common in Grout Brook and juvenile Chinook Salmon O. tshawytscha and Coho Salmon O. kisutch, as well as Fantail Darter Etheostoma flabellare in Orwell Brook.

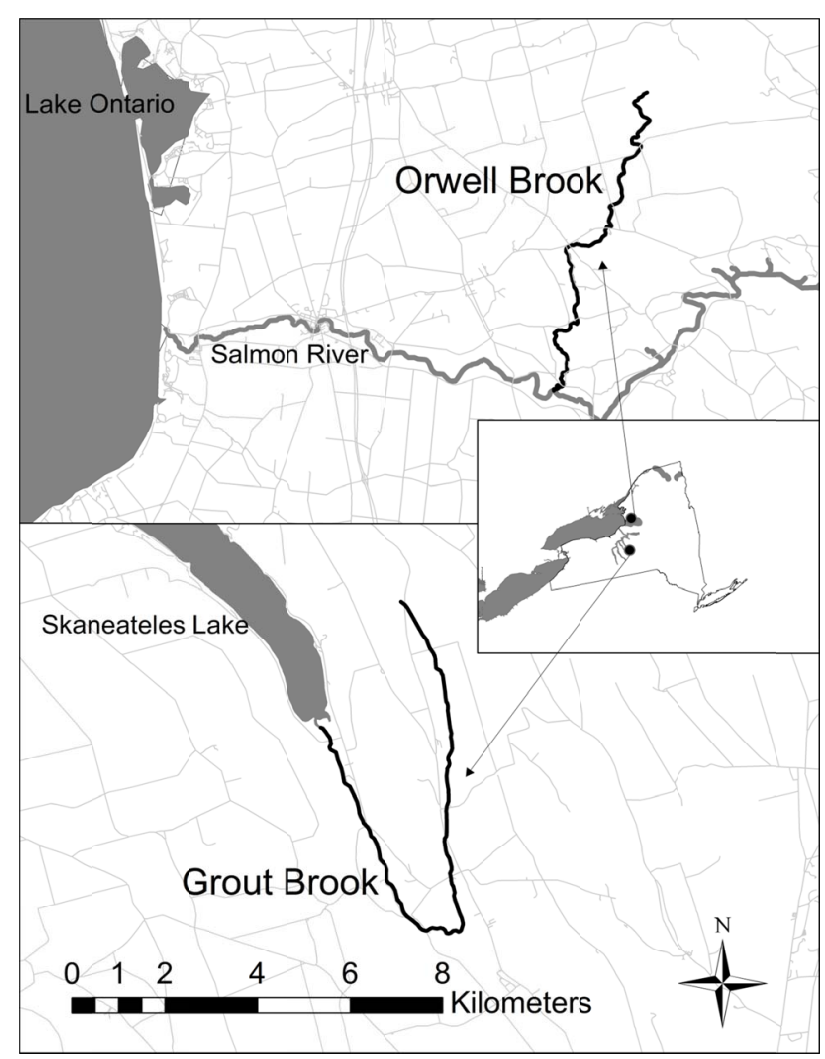

Fig. (1). Locations of study streams in the Lake Ontario watershed.

A representative study reach was established on each stream to conduct habitat assessments. The study reach in each stream was chosen after examining about $6 \mathrm{~km}$ of each stream and was selected based on being comprised of representative habitat found throughout the stream. In Grout Brook, the study reach was approximately $1 \mathrm{~km}$ in length and $0.7 \mathrm{~km}$ in Orwell Brook. Shallow water depth (mean depth in both streams $<20 \mathrm{~cm}$ ) in these streams precluded the use of some standard fish habitat assessment techniques, such as snorkeling that require deeper areas to be effective. Consequently, we used the spot-electrofishing method that is effective for examining fish habitat use in shallow water [12] for collecting yearling Rainbow Trout for habitat determination. When using this technique in small streams sampling should be conducted while moving upstream and sample sites must be placed a sufficient distance apart (i.e., $>3 \mathrm{~m}$ ) to minimize fish disturbance [13]. As with most fish collection methodologies, probability of capture may vary 
based on habitat type. At the location where each trout was collected a weighted, numbered buoy was placed. Habitat information collected at the location of each buoy included water depth $(\mathrm{cm})$, velocity $(\mathrm{cm} / \mathrm{s})$, substrate size, and the amount of cover. These habitat variables are considered most important to stream salmonids [14]. Water depth was measured with a wading rod and water velocity was measured with a Marsh-McBirney model 201-D digital flow meter at a depth of $0.6 \%$ from the water's surface. Cover and substrate size were estimated visually. Cover was usually quantified at 5\% increments as total available cover within a radius of four fish lengths [15] and generally consisted of substrate materials, surface turbulence, and vegetation. Considering that the average size of yearling Rainbow Trout in each stream was approximately $120 \mathrm{~mm}$, the radius for cover estimation was about $480 \mathrm{~mm}$. Substrate size was estimated using the modified Wentworth particle size scale with values of 1 (detritus), 2 (mud), 3 (silt), 4 (sand), 5 (gravel), 6 (rubble), 7 (boulder), and 8 (bedrock) [16]. On the day that yearling Rainbow Trout habitat was examined, available habitat was also quantified from transects spaced at $10 \mathrm{~m}$ intervals $(100$ transects in Trout Brook and 70 transects in Orwell Brook). Along each transect, available habitat information was collected at 5-8 stations spaced $0.5 \mathrm{~m}$ apart.

Bootstrapping cluster analysis [17] was used to evaluate differences in habitat use by Rainbow Trout in each stream and season relative to each other and available habitat. The four habitat variables were used as the attributes of conditions associated with locations where each Rainbow Trout was collected. The cluster analysis objectively identifies groups of entities (i.e. Rainbow Trout or available habitat by season) and used the Bray-Curtis similarity index, UPGMA linkage method, and 1000 bootstrap samples to test significance of each linkage. A non-parametric Kruskal-Wallis One-Way analysis of variance (Statistix 8.0 software, Tidepool Scientific, Tallahassee, FL) was used to examine differences in the seasonal habitat use of yearling Rainbow Trout and within season trout habitat and available habitat, because these variables were not normally distributed. The Dunn's Multiple Comparison Test was used to differentiate significant groups when differences were detected. Principal Component Analysis (PCA) was used to examine the ordination of Rainbow Trout habitat and available habitat variables in summer and autumn in each stream. An alpha level of $P<0.05$ was set to determine significance.

\section{RESULTS}

A total of 1,201 habitat observations were made on Rainbow Trout in Grout Brook (783) and Orwell Brook (418), during summer and autumn. An additional 2,705 observations were made on available habitat including 1,627 in Grout Brook and 1,078 in Orwell Brook. During summer in both streams, yearling Rainbow Trout occupied deeper and faster areas that had more cover than was generally available within the stream reach (Table 1). In autumn, yearling trout used areas that were deeper and had more cover compared to available habitat. In autumn in Orwell Brook yearling Rainbow Trout occupied significantly slower velocities compared to what was available in the stream reach (Table 1).

Table 1. Statistical analysis of mean (+/- SE) seasonal habitat use (depth, velocity, substrate, cover) for yearling Rainbow Trout (Oncorhynchus mykiss) and available habitat for Grout and Orwell Brook. Substrate values are categorical numbers based on the Wentworth scale. Values followed by a different letter down a column significantly differ $(P<0.05)$. RBT1+ = yearling Rainbow Trout, $\mathbf{A H}=$ available habitat.

\begin{tabular}{|c|c|c|c|c|}
\hline & Depth (cm) & Velocity $(\mathrm{cm} / \mathrm{s})$ & Substrate & \% Cover \\
\hline \multicolumn{5}{|l|}{ Grout Brook } \\
\hline RBT 1+ Fall & $28.3 \pm 1.2^{\mathrm{A}}$ & $28.4 \pm 2.1^{\mathrm{AB}}$ & $6.0 \pm 0.04^{\mathrm{A}}$ & $23.0 \pm 1.3^{\mathrm{A}}$ \\
\hline RBT 1+ Summer & $26.1 \pm 0.7^{\mathrm{A}}$ & $26.3 \pm 1.0^{\mathrm{AB}}$ & $5.9 \pm 0.02^{\mathrm{B}}$ & $23.9 \pm 0.6^{\mathrm{A}}$ \\
\hline AH Fall & $15.1 \pm 0.5^{\mathrm{B}}$ & $25.7 \pm 1.2^{\mathrm{B}}$ & $5.9 \pm 0.02^{\mathrm{B}}$ & $5.4 \pm 0.4^{\mathrm{B}}$ \\
\hline AH Summer & $14.5 \pm 0.4^{\mathrm{B}}$ & $22.7 \pm 0.7^{\mathrm{C}}$ & $5.9 \pm 0.02^{\mathrm{B}}$ & $6.1 \pm 0.3^{\mathrm{B}}$ \\
\hline$P$ & $<0.01$ & $<0.01$ & $<0.01$ & $<0.01$ \\
\hline F Stat (df) & $146(2408,3)$ & $4.47(2408,3)$ & $0.37(2408,3)$ & $415(2408,3)$ \\
\hline \multicolumn{5}{|l|}{ Orwell Brook } \\
\hline RBT 1+ Fall & $37.5 \pm 2.5^{\mathrm{A}}$ & $35.5 \pm 5.3^{\mathrm{B}}$ & $6.2 \pm 0.05^{\mathrm{A}}$ & $25.5 \pm 2.2^{\mathrm{A}}$ \\
\hline RBT 1+ Summer & $24.6 \pm 0.7^{\mathrm{B}}$ & $18.2 \pm 0.9^{\mathrm{C}}$ & $6.1 \pm 0.02^{\mathrm{B}}$ & $20.6 \pm 0.6^{\mathrm{B}}$ \\
\hline AH Fall & $20.5 \pm 0.5^{\mathrm{C}}$ & $50.4 \pm 1.9^{\mathrm{A}}$ & $6.1 \pm 0.01^{\mathrm{B}}$ & $6.6 \pm 0.4^{\mathrm{C}}$ \\
\hline AH Summer & $11.9 \pm 0.4^{\mathrm{D}}$ & $14.9 \pm 0.6^{\mathrm{C}}$ & $6.1 \pm 0.02^{\mathrm{B}}$ & $5.2 \pm 0.3^{\mathrm{C}}$ \\
\hline$P$ & $<0.01$ & $<0.01$ & 0.02 & $<0.01$ \\
\hline F Stat (df) & $154(1494,3)$ & $211(1494,3)$ & $165(1494,3)$ & $310(1494,3)$ \\
\hline
\end{tabular}

Seasonal variation was observed in available habitat in each stream. In Grout Brook, water velocity was higher in 
autumn than in summer. Conversely, compared to summer, water depth and water velocities were higher in Orwell Brook in autumn (Table 1). Although mean water velocity within each stream reach was significantly higher in both streams in autumn, the range of change was larger in Orwell Brook. In Grout Brook, mean water velocity increased from $22.7 \mathrm{~cm} / \mathrm{s}$ to $25.7 \mathrm{~cm} / \mathrm{s}$ from summer to autumn compared to an increase of $35.5 \mathrm{~cm} / \mathrm{s}$ to $50.4 \mathrm{~cm} / \mathrm{s}$ in Orwell Brook (Table 1). There was only minor difference in the habitat used by yearling Rainbow Trout between seasons in Grout Brook. In Orwell Brook in autumn, yearling trout occupied deeper and faster areas that had more cover and larger substrate compared to summer (Table 1).

Cluster analysis revealed no significant difference in available habitat between streams and no significant difference in Rainbow Trout habitat use between streams. However, a highly significant difference was observed between available habitat and the habitat used by yearling Rainbow Trout in each stream. Data from both streams were combined for PCA. The PCA axis 1 (strongly associated with cover and depth) explained 95.9\% and axis 2 (strongly associated with velocity and substrate) explained $4.1 \%$ of the variation in habitat variables in Grout Brook and Orwell Brook (Fig. 2). Yearling Rainbow Trout in Orwell Brook exhibited more seasonal variation in habitat use than trout in Grout Brook. In autumn stream discharge in Orwell Brook increased 564\% compared to only 117\% in Grout Brook. This difference was likely associated with greater variation in summer versus autumn stream discharge that occurred in Orwell Brook compared to Grout Brook. Compared to yearling Rainbow Trout habitat use in Grout Brook during both seasons and in Orwell Brook during summer, trout in Orwell Brook during the autumn occupied areas that were faster and had larger size substrate. Based on the distance between trout habitat use centroids, and available habitat centroids, there was no difference in habitat selection between streams or between seasons within a stream (Fig. 2).

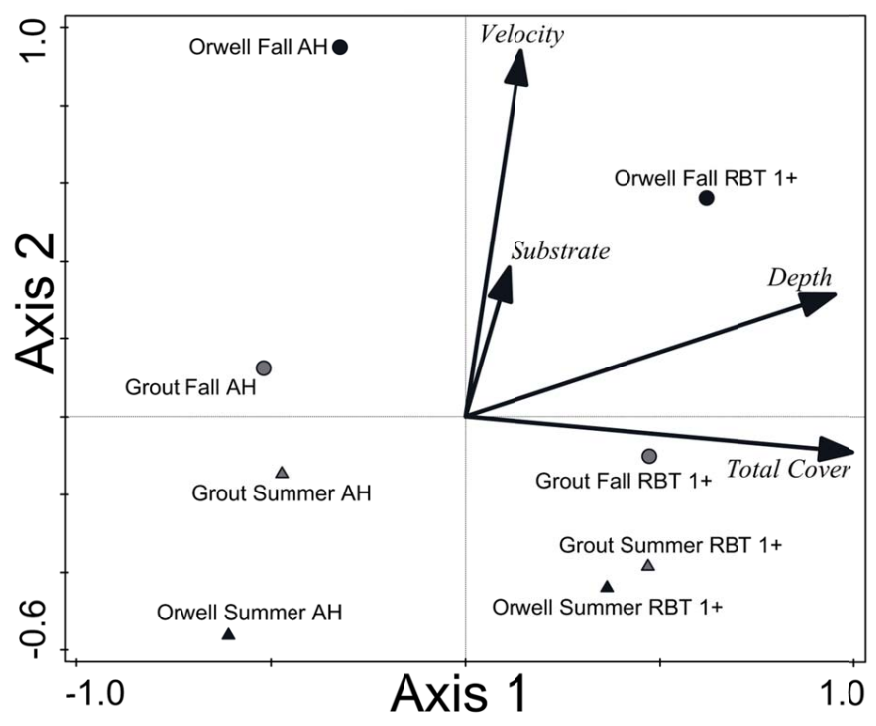

Fig. (2). Ordinal representation of yearling Rainbow Trout (Oncorhynchus mykiss) and available habitat using Principal Component Analysis in Grout Brook and Orwell Brook. RBT1+= yearling Rainbow Trout, AH = available habitat.

\section{DISCUSSION \& CONCLUSION}

Harvey et al. [18], found that the highest densities of yearling Rainbow Trout were associated with increased depth and cover. Salas and Snyder [19], also reported that the salmonid assemblage that included yearling Rainbow Trout in a tributary of the Manistee River, MI was associated with deeper areas during the day. However, important differences in the diel habitat use of yearling Rainbow Trout have been reported including the use of slower velocities at night [9], as well as more association with large woody debris [19]. Our observations on the diurnal habitat use of yearling Rainbow Trout in Grout Brook and Orwell Brook are consistent with these earlier studies; trout were associated with deeper areas with more cover compared to what was generally available within the stream reach.

In the Lake Ontario drainage, Rainbow Trout spawn in high gradient streams that have gravel-cobble substrate with abundant riparian overstory that helps maintain low summer water temperatures [20]. Higher stream flows in Orwell Brook during autumn likely influenced Rainbow Trout habitat use and resulted in greater separation of available habitat between seasons along the PCA velocity vector (axis 2) and was associated with a detectable shift in the habitat used by yearling Rainbow Trout. In autumn yearling Rainbow Trout in Orwell Brook occupied faster velocities than during 
summer and this likely reflected overall velocities in the stream that were significantly faster at this time. However, PCA also indicated that in Orwell Brook in autumn, trout were associated with larger substrates which may indicate that substrate materials were being used as a velocity barrier at this time. The use of velocity barriers by stream salmonids has been demonstrated to maximize net energy gain by minimizing energy expenditure at feeding stations while at the same time exploiting the greater rate of food supply in faster and deeper waters [21, 22]. Compared to summer, subyearling Coho Salmon have been also observed to use larger sized substrate when stream velocities were higher in the autumn in three Lake Ontario tributaries [23].

For migratory Rainbow Trout in the Great Lakes basin, understanding the habitat requirements of the largest size group of juveniles (i.e. yearlings) in tributaries prior to outmigration to the lake is especially important [3]. Our observations on the seasonal habitat use of yearling Rainbow Trout in these two streams provides valuable insights for resource managers tasked with protecting and restoring stream habitat. In particular, is the importance of pool habitat along with larger size substrate in this habitat that may provide current velocity barriers during high stream discharge events.

\section{CONFLICT OF INTEREST}

The authors confirm that this article content has no conflict of interest.

\section{ACKNOWLEDGEMENTS}

We thank Tim Wallbridge for assistance in the field. This article is contribution 2050 of the USGS Great Lakes Science Center. Any use of trade, firm, or product names is for descriptive purposes only and does not imply endorsement by the U.S. Government.

\section{REFERENCES}

[1] LeCren ED. The population dynamics of young trout in relation to density and territorial behavior. Rap Proces 1973; 164 : $241-6$.

[2] Chapman DW. Food and space as regulators of salmonid populations in streams. Am Nat 1966; 100: $345-57$. [http://dx.doi.org/10.1086/282427]

[3] Grant JW, Kramer DL. Territory size as a predictor of the upper limit to population density of juvenile salmonids in streams. Can J Fish Aquat Sci 1990; 47: 1724-37. [http://dx.doi.org/10.1139/f90-197]

[4] MacCrimmon HR, Gots BL. Rainbow Trout in the Great Lakes. Toronto, ON, Canada: Ontario Ministry of Natural Resources, Sport Fisheries Branch 1972; p. 66.

[5] McKenna JE Jr, Johnson JH. Juvenile rainbow trout production in New York tributaries of Lake Ontario: implications for Atlantic salmon restoration. N Am J Fish Manage 2005; 25: 391-403. [http://dx.doi.org/10.1577/M04-022.1]

[6] Johnson JH, Wedge LR. Interspecific competition in tributaries: prospectus for restoring Atlantic salmon in Lake Ontario. J Great Lakes Res 1999; 4: 11-7.

[7] Johnson JH, Ringler NH. Natural reproduction and juvenile ecology of Pacific salmon and O. mykiss in tributaries of the Salmon River, New York. NY Fish Game J 1981; 28: 49-60.

[8] Bradford MJ, Higgins PS. Habitat-, season-, and size-specific variation in diel activity patterns of juvenile Chinook Salmon (Oncorhynchus tchawytscha) and steelhead trout (Oncorhynchus mykiss). Can J Fish Aquat Sci 2001; 58: 365-74.

[http://dx.doi.org/10.1139/f00-253]

[9] Reeves GH, Grumbaum JB, Lang DW. Seasonal variation in diel behavior and habitat use by age 1+ steelhead (Oncorhynchus mykiss) in coast and Cascade range streams in Oregon, USA. Environ Biol Fishes 2010; 87: 101-11. [http://dx.doi.org/10.1007/s10641-009-9569-1]

[10] Hearn WE, Kynard BK. Habitat utilization and behavioral interaction of juvenile Atlantic salmon (Salmo salar) and O. mykiss (S. gairdneri) in tributaries of the White River of Vermont. Can J Fish Aquat Sci 1986; 43: 1988-98. [http://dx.doi.org/10.1139/f86-244]

[11] Rosenfeld J. Assessing the habitat requirements of stream fish: an overview and evaluation of different approaches. Trans Am Fish Soc 2003; 132: 953-68.

[http://dx.doi.org/10.1577/T01-126]

[12] Bovee KD. A guide to stream analysis using instream flow and incremental methodology. US Fish and Wildlife Service Instream Flow Information paper No. 12, Washington, D C 1982; pp. 248.

[13] Heggenes J, Brabrand A, Saltveit SJ. Comparison of three methods for studies of stream habitat use by young Brown Trout and Atlantic Salmon. Trans Am Fish Soc 1990; 119: 101-11. 
[http://dx.doi.org/10.1577/1548-8659(1990)119<0101:COTMFS $>2.3 . C O ; 2]$

[14] Heggenes J. Habitat utilization and preferences in juvenile Atlantic salmon (Salmo salar) in streams. Regul River 1990; 5: $341-54$. [http://dx.doi.org/10.1002/rrr.3450050406]

[15] Johnson JH, Dropkin DS. Seasonal habitat use by brook trout, Salvelinus fontinalis (Mitchill) in a second order stream. Fish Manag Ecol 1996; 3: 1-11. [http://dx.doi.org/10.1111/j.1365-2400.1996.tb00125.x]

[16] Orth DL, Jones RN, Maughan OE. Consideration in the development of habitat suitability criteria. In: Armantrout NB, Ed. Acquisition and utilization of Aquatic Habitat Inventory Information. Bethesda, MD: Western Division, American Fisheries Society 1981; pp. 124-33. [http://dx.doi.org/10.1016/S1364-8152(02)00094-4]

[17] McKenna JE Jr. An enhanced cluster analysis program with bootstrap significance testing for ecological community analysis. Environ Model Softw 2003; 18: 205-20. [http://dx.doi.org/10.1016/S1364-8152(02)00094-4]

[18] Harvey BC, White JL, Nakamoto RJ. Habitat-specific biomass, survival, and growth of O. mykiss (Oncorhynchus mykiss) during summer in a small stream. Can J Fish Aquat Sci 2005; 62: 650-8. [http://dx.doi.org/10.1139/f04-225]

[19] Salas AK, Snyder EB. Diel fish habitat selection in a tributary system. Am Midl Nat 2010; 163: 33-43. [http://dx.doi.org/10.1674/0003-0031-163.1.33]

[20] Johnson JH. McKenna Jr., JE, Douglass KA. Movement and feeding ecology of recently emerged steelhead in Lake Ontario tributaries. J Appl Ichthyol 2013; 29: 222-5.

[http://dx.doi.org/10.1111/jai.12032]

[21] Chapman DW, Bjornn TC. Distribution of salmonids in streams, with special reference to food and feeding. In: Northcote TG, Ed. Symposium on Salmon and Trout in Streams. Vancouver: University of British Columbia 1969; pp. 153-76.

[22] Fausch KD. Profitable stream positions for salmonids: relating specific growth rate to net energy gain. Can J Zool 1984; 62: 441-51. [http://dx.doi.org/10.1139/z84-067]

[23] Johnson JH. Habitat use by subyearling Chinook and Coho Salmon in Lake Ontario tributaries. J Great Lakes Res 2014; 40 : 149-54. [http://dx.doi.org/10.1016/j.jglr.2013.12.006]

(C) Johnson et al.; Licensee Bentham Open

This is an open access article licensed under the terms of the Creative Commons Attribution-Non-Commercial 4.0 International Public License (CC BY-NC 4.0) (https://creativecommons.org/licenses/by-nc/4.0/legalcode), which permits unrestricted, non-commercial use, distribution and reproduction in any medium, provided the work is properly cited. 